\title{
Experimental study of physical and rheological properties of grape juice using different temperatures and concentrations. Part I: Cabernet Sauvignon
}

\author{
Maurício Bonatto Machado de Castilhos*, Lilian Fachin Leonardo Betiol, \\ Gisandro Reis de Carvalho, Javier Telis-Romero
}

São Paulo State University - UNESP, Institute of Biosciences, Humanities and Exact Sciences - IBILCE, Campus São José do Rio Preto, Food Engineering and Technology Department - DETA, Cristóvão Colombo St. 2265, 15054-000, São José do Rio Preto, Brazil

\section{A R T I C L E I N F O}

\section{Keywords:}

Rheology

Physical properties

Cabernet Sauvignon

Grape juice

Activation energy

\begin{abstract}
A B S T R A C T
The effect of the temperature and concentration on rheological behavior of Cabernet Sauvignon juice concentrates was assessed using a rheometer over a wide range of temperature $\left(1-66^{\circ} \mathrm{C}\right)$ and concentrations (13.6-45.0 Brix) at shear rates of 0.84-212.1 1/s. The Ostwald-De Waele was the best rheological model fitted the data $\left(\mathrm{R}^{2}=0.99957\right.$ and relative error $\left.=7.77 \%\right)$. The Cabernet Sauvignon juice concentrates presented a non-Newtonian pseudoplastic behavior $(n<1)$. The consistency levels were significantly reduced with the increase of temperature and increased with the increase of the concentrations. The flow activation energy ranged from 28.87 (45.0 Brix) to $38.05 \mathrm{KJ} / \mathrm{mol}$ (37.0 Brix) with a $\mathrm{R}^{2}=0.9798$ for both cases. Density and specific heat were influenced by both temperature and concentration; however, thermal conductivity was only influenced by concentration. The Cabernet Sauvignon juice concentrates will be useful as wine chaptalization agent in future studies.
\end{abstract}

\section{Introduction}

Cabernet Sauvignon grape cultivar, originated from the region of Bordeaux, France, is currently widespread in most wine countries. It presents a particular taste and a high resistance to fungal contamination. This cultivar is considered one of the most important Vitis vinifera grape which are used to produce juices and wines with high quality and specific features and it is considered a potential grape for the production of young red wines or wines submitted to maturation in oak barrels (Rizzon \& Miele, 2002). Cabernet Sauvignon grape presents in its composition, a high content of phenolic compounds that is responsible for the high antioxidant activity, property that allows the reduction of the risk of coronary heart diseases and atherosclerosis. Due to this, the consumption of juices and wines produced from this type of grape cultivar is strongly recommended (Radovanovic, Jovancicevic, Arsic, Radovanovic, \& Bukarica, 2016).

Rheological studies are important for the design of unit operations, high quality assurance of foods and beverages and process optimization. In addition, rheological approaches are employed mainly as essential tools for food engineering, since rheology is linked to food processing and stability, as well as to sensory perceptions. The physical properties of density, specific heat and thermal conductivity present high importance for food and beverages, mainly for juices, since these aforementioned properties are closely related to sensory features (Augusto, Ibarz, \& Cristianini, 2012; Neto, De Castilhos, Telis, \& TelisRomero, 2014).

There have been many studies concerning the rheological behavior of juices from different botanical sources; however, there is a lack in studies that present rheological data regarding grape juices. The orange juice density and the energy dissipated as heat were correlated with different degrees of pectin extraction in a study of Galant, Widmer, Luzio, and Cameron (2014); Zuritz et al. (2005) reported the density, the rheological behavior and the activation energy of clarified Cereza, Criolla and Moscatel Rosada grape juices and the influence of the temperature and the soluble solid contents in these properties; rheological properties and fluid rheological behavior were also determined for peach juice processed by ultrasound technology (Rojas, Leite, Cristianini, Alvim, \& Augusto, 2016) and for soursoup fruits (Quek, Chin, \& Yusof, 2013).

In this context, the study of the Cabernet Sauvignon juice rheological behavior and physical properties is relevant for the juice industries and mainly for the wine producers, since this grape cultivar presents a great wine potential. In Brazil, for example, there is a procedure that is allowed by legislation, known as chaptalization, that consists in adding

\footnotetext{
* Corresponding author at: São Paulo State University - UNESP, Institute of Biosciences, Humanities and Exact Sciences - IBILCE, Campus São José do Rio Preto, Food Engineering and Technology Department - DETA, Cristóvão Colombo street, 2265, São José do Rio Preto, São Paulo, Brazil.

E-mail address: mbonattosp@yahoo.com.br (M.B.M. de Castilhos).
} 
sucrose in the grape juice in order to correct the alcohol content of the resulting wine (Brasil, 2005). A possible alternative for the substitution of the sucrose as chaptalization agent is the insertion of concentrated juice of the same grape cultivar in order to maintain the wine features. Since this procedure is not applied in winemaking yet, the study of the rheological behavior of this type of juice become suitable and relevant.

Based on the above considerations, the present study aimed at evaluating the rheological behavior of Cabernet Sauvignon juice at different concentrations and temperatures and, additionally, predict a possible influence of these aforementioned parameters on density, specific heat and thermal conductivity.

\section{Material and methods}

\subsection{Juice samples}

Cabernet Sauvignon grape juice (Vitis vinifera) was produced from grapes grown in Santa Catarina State, Brazil. The grape juices were obtained directly from the producers and they were classified as "readyto-drink". A visual assessment showed that they presented no particulate matter. The juice (initial 12.2 Brix) was concentrated to 13.6, 21.0, 29.0, 37.0 and 45 Brix in a rotary low pressure evaporator (Marconi MA 130 ) at $44{ }^{\circ} \mathrm{C}$. The soluble solid content of the juice and concentrates was assessed by a refractometer (PAL-BX/RI-Atago). All samples remained at rest for at least $24 \mathrm{~h}$ before being submitted to rheological measurements.

\subsection{Rheological characterization}

Steady shear rheological tests were carried out in a controlled stress rheometer, model ARG2 (TA Instruments, New Castle, USA) using a concentric cylinder geometry (inner cylinder $-42 \mathrm{~mm} \times 28 \mathrm{~mm}$; outer cylinder $-78.5 \mathrm{~mm} \times 30.15 \mathrm{~mm}$ ) with $5920 \mu \mathrm{m}$ gap under controlled stress and temperature, the latter controlled by a Peltier system. The system was controlled by the Rheology Advantage software, in which steady flow was reached ranging shear rate from 0.84 to $212.1 \mathrm{~s}^{-1}$ at different temperatures $\left(1,10,19,28,37,46,56\right.$ and $\left.66^{\circ} \mathrm{C}\right)$. These temperatures were chosen based on the pasteurization process, since the grape juice is pasteurized before its application in wineries and before consumption.

The steady state was obtained for each shear rate and a brief study was conducted in order to evaluate the necessary time to reach steady state conditions. These high temperatures were chosen aiming at covering a wide range of temperature. The accuracy of the rheometer was previously done using a rheological study of chlorobenzene and acetic acid (50:50 v/v) as standard substances according to Neto et al. (2014).

The rheological models were fitted to the experimental shear stress and shear rate data using the nonlinear estimation procedure of Statistica software StatSoft Inc. (2014). The experimental data were fitted to four rheological models as follows: Newton law of viscosity (Eq. (1)), Ostwald-de Waele (Eq. (2)), Bingham (Eq. (3)) and HerschelBulkley (Eq. (4)). This approach allowed the determination of the rheological parameters, which could be correlated with the aforementioned temperatures. The best rheological model that fitted the experimental data was selected according to the coefficient of determination $\left(\mathrm{R}^{2}\right)$ as well as by the minimization of the relative error (Eq. (5)) between observed and predicted values.

$\tau=\mu \gamma$

$\tau=\mathrm{k}(\gamma)^{n}$

$\tau=\tau_{0}+\mathrm{k} \gamma$

$\tau=\tau_{0}+\mathrm{k}(\gamma)^{n}$

Error $(\%)=\frac{\mid \text { observed }- \text { predicted } \mid}{\text { observed }} \times 100$

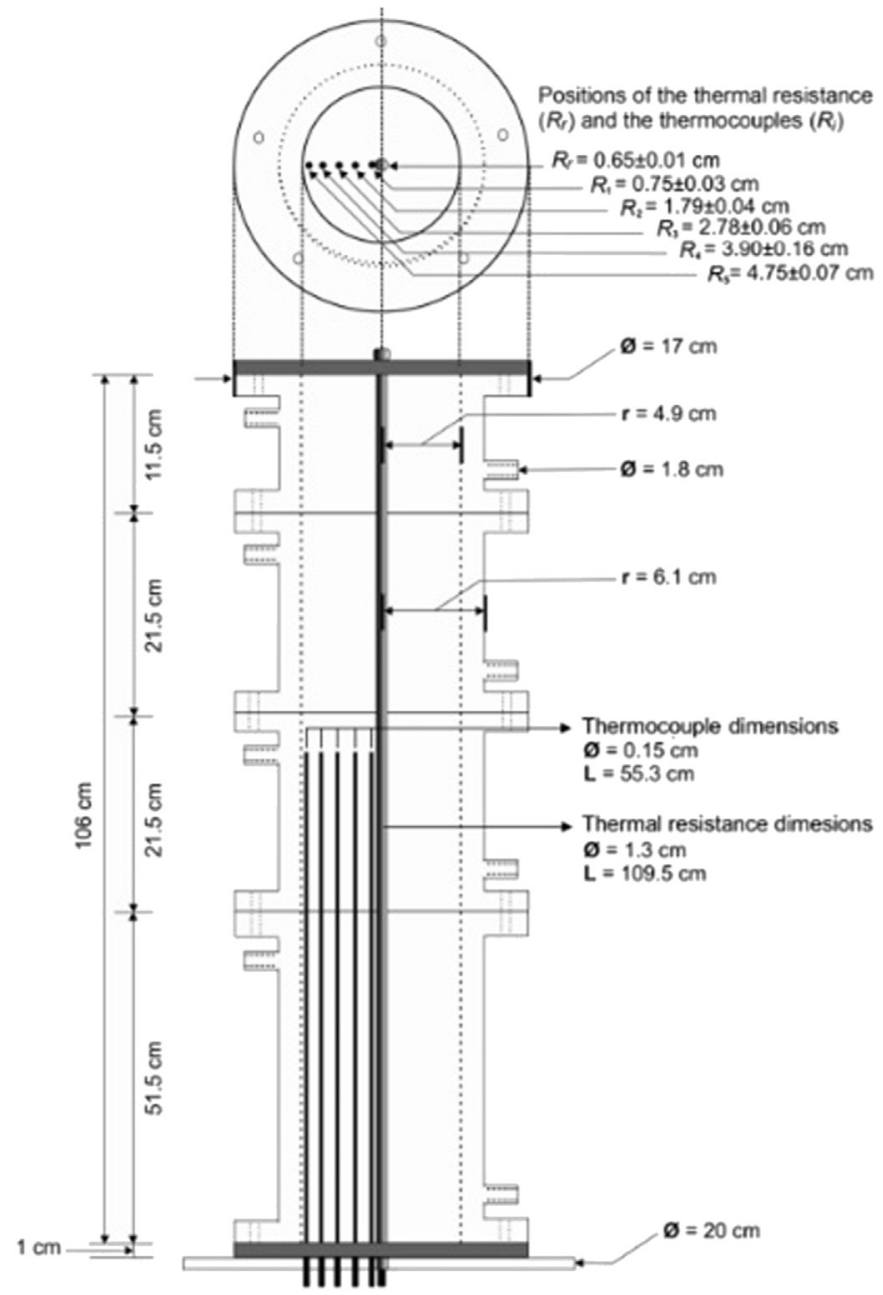

Fig. 1. Apparatus used to determine the thermal conductivity.

Table 1

Coefficient of determinations of Cabernet Sauvignon concentrates obtained by fitting the experimental data to the rheological models.

\begin{tabular}{llll}
\hline Model name & Model equation & $\mathrm{R}^{2}$ & Relative error (\%) \\
\hline Newtonian & $\tau=\mu \gamma$ & $0.99933 \pm 0.0003$ & $25.75 \pm 9.7$ \\
Ostwald-de Waele & $\tau=\mathrm{k}(\gamma)^{n}$ & $0.99957 \pm 0.0005$ & $7.77 \pm 5.9$ \\
Bingham & $\tau=\tau_{0}+\mathrm{k} \gamma$ & $0.99933 \pm 0.0003$ & $20.21 \pm 8.5$ \\
Herschel-Bulkley & $\tau=\tau_{0}+\mathrm{k}(\gamma)^{\mathrm{n}}$ & $0.99957 \pm 0.0005$ & $8.58 \pm 6.2$ \\
\hline
\end{tabular}

The different values of $\mathrm{n}$ indicate the fluid behavior, i.e., $n=1$ for Newtonian or Bingham plastic fluid, $n<1$ for pseudoplastic fluid and $n>1$ for dilatant fluid.

The rheological parameters as consistency level $(k)$ and viscosity $(\mu)$ are influenced by temperature and the effect of this aforementioned variable was studied by fitting the rheological data to the Arrhenius equation (Eq. (6)):

$k=k_{0} \exp \left(\frac{E_{a}}{R T}\right)$

As only the consistency level dependency was assessed, in this expression $k_{0}$ is an empirical constant, $R$ is the universal gas constant ( $8.314 \mathrm{~J} \mathrm{~mol} \mathrm{~K}^{-1}$ ), $T$ is the absolute temperature $(\mathrm{K})$ and $E_{a}\left(\mathrm{KJ} \mathrm{mol}^{-1}\right.$ ) is the activation energy required for the flow (Telis-Romero, Thomaz, Bernardi, Telis, \& Gabas, 2006). 

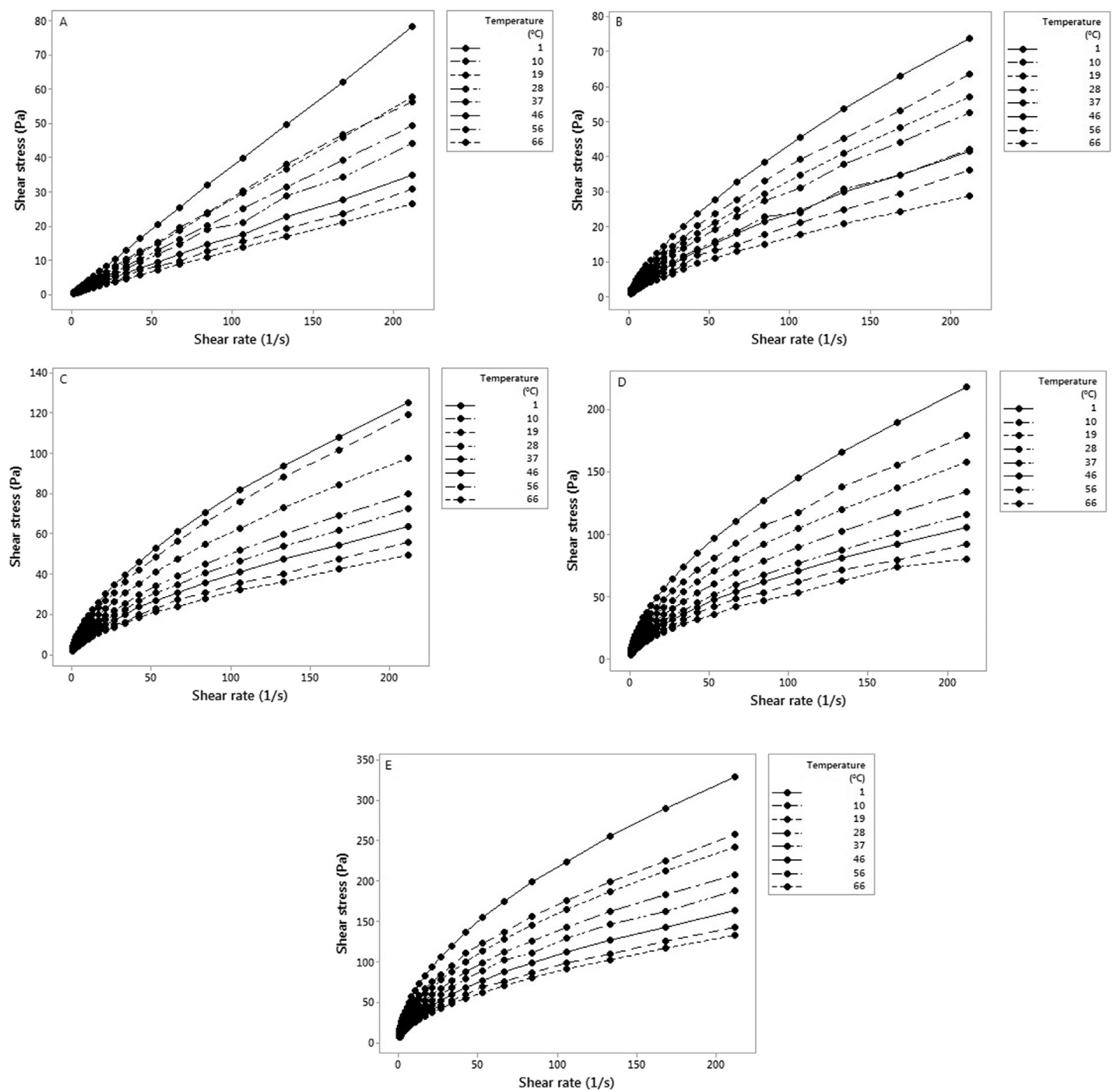

Fig. 2. Rheological behavior of the Cabernet Sauvignon concentrates according to the different temperatures and soluble solid contents. (A) 13.6 Brix, (B) 21.0 Brix, (C) 29.0 Brix, (D) 37.0 Brix and (E) 45.0 Brix.

\subsection{Determination of physical properties}

\subsubsection{Density}

Cabernet Sauvignon juices density was determined in triplicate using a digital electronic densimeter (model DMA 4500-M, Anton Paar, Austria) at the same temperature range as done for rheological assays. These temperatures were established in the own equipment after inserting approximately $50 \mathrm{~mL}$ of each juice for density measurements. The equipment performance was evaluated using aqueous solution of acetic acid (50:50 v/v) by Neto et al. (2014) with well-known densities described by Perry \& Chilton (1986).

\subsubsection{Thermal conductivity}

The effective thermal conductivity of the juice was measured at different moisture contents and temperature by a steady-state technique. The apparatus used (Fig. 1) consists of a jacketed cylindrical cell (106 cm long, $9.8 \mathrm{~cm}$ inner diameter, $12.2 \mathrm{~cm}$ outer diameter) of stainless steel divided in four modules. A thermal resistance of $200 \mathrm{~W}$, located along the axis of the cell, provided a uniform heat flux during the experiments. Both ends of the apparatus were isolated with Teflon discs $(1 \mathrm{~cm}$ thickness, $17 \mathrm{~cm}$ diameter) to prevent axial heat transfer. The power input to the heater resistance was regulated by a laboratory DC power supply (MPS-3006D, Minipa, São Paulo, Brazil), which allowed to adjust the current with a stability of $0.05 \%$. Five type-J thermocouples were fixed between the surfaces of the resistance and the inner cylinder allowing the measurements of the temperature (Fig. 1). Temperatures were monitored using a data logger (NI 9213, National Instruments, Austin, USA) and a program for data acquisition developed in LabVIEW (National Instruments, Austin, USA). During the experiments, cold water passed through the jacket from a thermostatic bath (MA-184, Marconi, São Paulo, Brazil) in order to control the temperature in the inner surface of the cell.

Experiments were performed in triplicate by loading the cell with juice at the different moisture contents and monitoring the temperature profile during heating at constant heat flux. When the deviation among the temperatures within the cell was almost constant, steady state conditions could be assumed and thermal conductivity $(k)$ ( $\mathrm{W} \mathrm{m} \mathrm{m}^{-1}{ }^{\circ} \mathrm{C}^{-1}$ ) could be calculated from the unidirectional radial heat 
Table 2

Mean \pm standard deviation of rheological parameters of Ostwald-de Waele equation of Cabernet Sauvignon juice concentrates at various concentrations and temperatures.

\begin{tabular}{|c|c|c|c|c|c|}
\hline \multirow[t]{2}{*}{ Temperature $\left({ }^{\circ} \mathrm{C}\right)$} & \multicolumn{5}{|l|}{ Concentration (Brix) } \\
\hline & 13.6 & 21.0 & 29.0 & 37.0 & 45.0 \\
\hline \multicolumn{6}{|c|}{ Consistency level, k (Pa.s $\left.{ }^{\mathrm{n}}\right)$} \\
\hline 1 & $0.4238 \pm 0.0034^{\mathrm{a}}$ & $1.6408 \pm 0.0034^{\mathrm{a}}$ & $4.4261 \pm 0.0322^{\mathrm{a}}$ & $9.4036 \pm 0.0006^{\mathrm{a}}$ & $17.4406 \pm 0.0081^{\mathrm{a}}$ \\
\hline 10 & $0.3655 \pm 0.0031^{b}$ & $1.3621 \pm 0.0380^{\mathrm{b}}$ & $3.7005 \pm 0.0108^{\mathrm{b}}$ & $8.1722 \pm 0.0041^{b}$ & $14.5862 \pm 0.0103^{\mathrm{b}}$ \\
\hline 19 & $0.3102 \pm 0.0022^{\mathrm{c}}$ & $1.1967 \pm 0.0043^{\mathrm{c}}$ & $3.2958 \pm 0.0010^{c}$ & $6.9610 \pm 0.0110^{c}$ & $12.7937 \pm 0.0273^{c}$ \\
\hline 28 & $0.2635 \pm 0.0033^{\mathrm{d}}$ & $1.0603 \pm 0.0024^{\mathrm{d}}$ & $2.8425 \pm 0.0008^{\mathrm{d}}$ & $6.0643 \pm 0.0126^{\mathrm{d}}$ & $11.1870 \pm 0.0301^{\mathrm{d}}$ \\
\hline 37 & $0.2461 \pm 0.0013^{\mathrm{e}}$ & $0.9453 \pm 0.0020^{\mathrm{e}}$ & $2.4615 \pm 0.0145^{\mathrm{e}}$ & $5.2826 \pm 0.0143^{\mathrm{e}}$ & $9.8102 \pm 0.0556^{\mathrm{e}}$ \\
\hline 46 & $0.2146 \pm 0.0015^{\mathrm{f}}$ & $0.8228 \pm 0.0003^{\mathrm{f}}$ & $2.1794 \pm 0.0368^{\mathrm{f}}$ & $4.7061 \pm 0.0017^{\mathrm{f}}$ & $8.6785 \pm 0.0144^{f}$ \\
\hline 56 & $0.1755 \pm 0.0003^{g}$ & $0.6773 \pm 0.0208^{g}$ & $1.8815 \pm 0.0046^{g}$ & $4.1573 \pm 0.0196^{g}$ & $7.6167 \pm 0.0044^{g}$ \\
\hline 66 & $0.1626 \pm 0.0003^{\mathrm{h}}$ & $0.6238 \pm 0.0076^{\mathrm{h}}$ & $1.7373 \pm 0.0005^{\mathrm{h}}$ & $3.7240 \pm 0.0121^{\mathrm{h}}$ & $6.7479 \pm 0.0281^{\mathrm{h}}$ \\
\hline $\mathrm{P}_{\text {value }}{ }^{1}$ & $<0.001$ & $<0.001$ & $<0.001$ & $<0.001$ & $<0.001$ \\
\hline \multicolumn{6}{|c|}{ Flow behavior index, $\mathrm{n}$} \\
\hline 1 & $0.9732 \pm 0.0016^{\mathrm{ab}}$ & $0.7117 \pm 0.0004^{\mathrm{bc}}$ & $0.6240 \pm 0.0016^{\mathrm{d}}$ & $0.5863 \pm 0.0001^{\mathrm{a}}$ & $0.5486 \pm 0.0000^{c}$ \\
\hline 10 & $0.9451 \pm 0.0017^{\mathrm{d}}$ & $0.7166 \pm 0.0056^{\mathrm{bc}}$ & $0.6477 \pm 0.0006^{\mathrm{a}}$ & $0.5766 \pm 0.0000^{\mathrm{d}}$ & $0.5342 \pm 0.0000^{\mathrm{d}}$ \\
\hline 19 & $0.9752 \pm 0.0011^{\mathrm{a}}$ & $0.7216 \pm 0.0056^{\mathrm{ab}}$ & $0.6326 \pm 0.0003^{\mathrm{b}}$ & $0.5815 \pm 0.0003^{\mathrm{b}}$ & $0.5482 \pm 0.0004^{c}$ \\
\hline 28 & $0.9767 \pm 0.0027^{\mathrm{a}}$ & $0.7288 \pm 0.0002^{\mathrm{a}}$ & $0.6218 \pm 0.0001^{\mathrm{d}}$ & $0.5774 \pm 0.0003^{\mathrm{cd}}$ & $0.5458 \pm 0.0005^{c}$ \\
\hline 37 & $0.9686 \pm 0.0008^{\mathrm{b}}$ & $0.7080 \pm 0.0004^{c}$ & $0.6295 \pm 0.0009^{\mathrm{bc}}$ & $0.5749 \pm 0.0005^{\mathrm{d}}$ & $0.5510 \pm 0.0011^{\mathrm{b}}$ \\
\hline 46 & $0.9496 \pm 0.0012^{\mathrm{d}}$ & $0.7317 \pm 0.0002^{\mathrm{a}}$ & $0.6282 \pm 0.0031^{\mathrm{cd}}$ & $0.5804 \pm 0.0001^{\mathrm{bc}}$ & $0.5479 \pm 0.0002^{\mathrm{c}}$ \\
\hline 56 & $0.9587 \pm 0.0006^{\mathrm{c}}$ & $0.7360 \pm 0.0055^{\mathrm{a}}$ & $0.6290 \pm 0.0004^{\mathrm{bc}}$ & $0.5780 \pm 0.0008^{\mathrm{cd}}$ & $0.5473 \pm 0.0000^{c}$ \\
\hline 66 & $0.9484 \pm 0.0009^{\mathrm{d}}$ & $0.7158 \pm 0.0021^{\mathrm{bc}}$ & $0.6243 \pm 0.0000^{\mathrm{cd}}$ & $0.5727 \pm 0.0021^{\mathrm{d}}$ & $0.5561 \pm 0.0009^{\mathrm{a}}$ \\
\hline$P_{\text {value }}{ }^{1}$ & $<0.001$ & $<0.001$ & $<0.001$ & $<0.001$ & $<0.001$ \\
\hline
\end{tabular}

${ }^{1}$ Different letters in the same column indicate significant differences according to Analysis of Variance and post-hoc Tukey's test ( $\left.\alpha=0.05\right)$.

Table 3

Parameters of Arrhenius equation, frequency factor and activation energy of Cabernet Sauvignon juice concentrates at various concentrations.

\begin{tabular}{llll}
\hline Concentration (Brix) & $\mathrm{k}_{0}\left(\mathrm{~Pa} \mathrm{~s}^{\mathrm{n}}\right)$ & $\mathrm{E}_{\mathrm{a}}(\mathrm{KJ} / \mathrm{mol})$ & \multicolumn{1}{l}{$\mathrm{R}^{2}$} \\
\hline 13.6 & $0.2498 \pm 0.001^{\mathrm{e}}$ & $37.30 \pm 1.6^{\mathrm{ab}}$ & $0.9792 \pm 0.0007$ \\
21.0 & $0.9593 \pm 0.001^{\mathrm{d}}$ & $35.77 \pm 3.0^{\mathrm{ab}}$ & $0.9828 \pm 0.0008$ \\
29.0 & $2.4925 \pm 0.012^{\mathrm{c}}$ & $30.86 \pm 2.1^{\mathrm{ab}}$ & $0.9790 \pm 0.0008$ \\
37.0 & $5.3571 \pm 0.020^{\mathrm{b}}$ & $38.05 \pm 2.8^{\mathrm{a}}$ & $0.9798 \pm 0.0006$ \\
45.0 & $9.9182 \pm 0.052^{\mathrm{a}}$ & $28.87 \pm 0.9^{\mathrm{b}}$ & $0.9798 \pm 0.0011$ \\
P value $^{1}$ & $<0.001$ & 0.029 & \\
\hline
\end{tabular}

${ }^{1}$ Different letters in the same column indicate significant differences according to Analysis of Variance and post-hoc Tukey's test ( $\alpha=0.05)$.

transfer equation (Eq. (7)), as described by Fourier equation in cylindrical coordinates with the boundary conditions corresponding to the transfer between the two concentric cylindrical surfaces kept at constant temperatures (Carvalho, Chenlo, Moreira, \& Telis-Romero, 2015; Telis-Romero, Gabas, Polizelli, \& Telis, 2000) and considering heat supplied by the thermal resistance $(q)(W)$ was equal to the heat that passed through the juice:

$k=q \frac{\ln \left(\frac{R_{1}}{R_{5}}\right)}{2 \pi l\left(T_{5}-T_{1}\right)}$

where $l$ is the cell length (m), $R_{1}$ and $R_{5}$ are the radial positions (m) of the thermocouple closest to the thermal resistance and the thermocouple closest to the inner surface of the cell, respectively, and $T_{1}$ and $T_{5}$ are the steady state temperatures $\left({ }^{\circ} \mathrm{C}\right)$ at $R_{1}$ and $R_{5}$, respectively.

\subsubsection{Specific heat measurements}

The specific heat capacity was measured by a DSC 8000 (Perkin Elmer, Shelton, CT). The DSC instrument was calibrated with indium (m.p. $=156.6{ }^{\circ} \mathrm{C}, h_{\mathrm{f}}=28.45 \mathrm{~J} / \mathrm{g}$ ) at a heating rate of $10{ }^{\circ} \mathrm{C} / \mathrm{min}$. The purge gas was nitrogen (purity, 99.5\%) with a flow rate of approximately $20 \mathrm{~mL} / \mathrm{min}$. Sample liquid aluminum pans weighing $24.01 \pm 0.04 \mathrm{mg}$ (ref. 0219-0062, Perkin Elmer, USA) were used as the baseline, and also as recipients for the reference material (Arched, 1993). Samples were sealed and weighed before and after the experimental procedures. The baseline material, reference material, and samples were subjected to the following temperature program: isothermal $0{ }^{\circ} \mathrm{C}$ for $4 \mathrm{~min}$, heat flow of $10{ }^{\circ} \mathrm{C} / \mathrm{min}$ to $60^{\circ} \mathrm{C}$, and isothermal for $4 \mathrm{~min}$, according to the ASTM-E1269 method (ASTM, 2005). The PYRIS 10.1 software (Perkin Elmer, Shelton, CT) was used to analyze the thermal data. The specific heat capacity $\left(c_{\mathrm{p}}, \mathrm{J} / \mathrm{kg}{ }^{\circ} \mathrm{C}\right)$ of the concentrates was calculated using (Eq. (8)) where $D_{\mathrm{s}}$ is the net thermal power with respect to a reference material at a given temperature $(\mathrm{mW}), W_{\mathrm{s}}$ is the sample mass $(\mathrm{mg})$ and $\theta$ is the heating rate $\left({ }^{\circ} \mathrm{C} / \mathrm{s}\right)$.

$c_{p}=\frac{D_{S}}{W_{S} \theta}$

\subsection{Data analysis}

The experiment was repeated three times and each sample was collected in triplicate. The data were analyzed using a completely randomized design in order to avoid carryover effects. The statistical significance of the rheological parameters and physical properties was evaluated by Analysis of Variance (ANOVA) followed by Tukey's multiple comparison post-hoc test with $P<0.05$. Statistical approach was performed using the software Minitab 15 (Lead Technologies, State College, PA, USA).

\section{Results and discussion}

\subsection{Rheological behavior of cabernet sauvignon juice concentrates}

The rheological data of Cabernet Sauvignon juice concentrates obtained were fitted to the aforementioned rheological models and the coefficient of determinations $\left(\mathrm{R}^{2}\right)$ and the relative errors (\%) are shown in Table 1.

All models showed high values of goodness of fitting with $\mathrm{R}^{2}>0.999$; however, both Ostwald-de Waele and Herschel-Bulkley models were more perfectly fitted to the experimental data with $\mathrm{R}^{2}=0.99957$. In addition, the lower relative error was observed for Ostwald-de Waele model $(7.77 \pm 5.9 \%)$ indicating that the assessed fluids were better adjusted to this aforementioned rheological model. In all Brix assessed, the Herschel-Bulkley fitting, a three parameter rheological model, resulted in negative stress values which are meaningless in a physical point of view (Gratão, Silveira, \& Telis-Romero, 2007) and 
Table 4

Mean \pm standard deviation of density, specific heat and thermal conductivity from Cabernet Sauvignon juices.

\begin{tabular}{|c|c|c|c|c|c|c|}
\hline \multirow[t]{3}{*}{ Temperature $\left({ }^{\circ} \mathrm{C}\right)$} & \multicolumn{5}{|l|}{ Density $\left(\mathrm{kg} \mathrm{m}^{-3}\right)$} & \multirow{3}{*}{$P$ value } \\
\hline & \multicolumn{5}{|l|}{ Brix } & \\
\hline & 13.6 & 21.0 & 29.0 & 37.0 & 45.0 & \\
\hline 1 & $1046.1 \pm 2^{\mathrm{aE}}$ & $1081.6 \pm 2^{\mathrm{aD}}$ & $1118.5 \pm 1^{\mathrm{aC}}$ & $1158.8 \pm 5^{\mathrm{aB}}$ & $1197.2 \pm 6^{\mathrm{aA}}$ & $<0.001$ \\
\hline 10 & $1043.0 \pm 0^{\mathrm{abE}}$ & $1078.5 \pm 2^{\mathrm{abD}}$ & $1115.4 \pm 1^{\mathrm{abC}}$ & $1155.3 \pm 4^{\mathrm{aB}}$ & $1194.9 \pm 7^{\mathrm{abA}}$ & $<0.001$ \\
\hline 19 & $1039.8 \pm 0^{\mathrm{bcE}}$ & $1075.7 \pm 2^{\mathrm{abcD}}$ & $1112.8 \pm 2^{\mathrm{abcC}}$ & $1152.3 \pm 4^{\mathrm{abB}}$ & $1192.1 \pm 7^{\mathrm{abA}}$ & $<0.001$ \\
\hline 28 & $1037.3 \pm 1^{\mathrm{cdE}}$ & $1072.6 \pm 2^{\mathrm{bcD}}$ & $1110.9 \pm 3^{\mathrm{abcdC}}$ & $1149.4 \pm 5^{\mathrm{abcB}}$ & $1189.6 \pm 8^{\mathrm{abA}}$ & $<0.001$ \\
\hline 37 & $1034.7 \pm 2^{\mathrm{deE}}$ & $1071.1 \pm 4^{\mathrm{bcdD}}$ & $1108.3 \pm 4^{\mathrm{bcdC}}$ & $1146.2 \pm 5^{\mathrm{abcB}}$ & $1186.4 \pm 8^{\mathrm{abcA}}$ & $<0.001$ \\
\hline 46 & $1031.6 \pm 2^{\mathrm{fE}}$ & $1067.6 \pm 4^{\mathrm{cdD}}$ & $1105.2 \pm 4^{\mathrm{cdeC}}$ & $1144.9 \pm 7^{\mathrm{abcB}}$ & $1183.3 \pm 8^{\mathrm{abcA}}$ & $<0.001$ \\
\hline 56 & $1028.1 \pm 2^{\mathrm{fgE}}$ & $1064.1 \pm 4^{\mathrm{deD}}$ & $1101.7 \pm 4^{\mathrm{deC}}$ & $1139.6 \pm 5^{\mathrm{bcB}}$ & $1177.2 \pm 5^{\mathrm{bcA}}$ & $<0.001$ \\
\hline 66 & $1024.6 \pm 2^{\mathrm{gE}}$ & $1058.3 \pm 1^{\mathrm{eD}}$ & $1098.5 \pm 5^{\mathrm{eC}}$ & $1136.6 \pm 5^{\mathrm{cB}}$ & $1167.7 \pm 5^{\mathrm{cA}}$ & $<0.001$ \\
\hline$P$ value & $<0.001$ & $<0.001$ & $<0.001$ & 0.001 & 0.002 & \\
\hline
\end{tabular}

\begin{tabular}{|c|c|c|c|c|c|c|}
\hline \multirow[t]{3}{*}{ Temperature $\left({ }^{\circ} \mathrm{C}\right)$} & \multicolumn{5}{|c|}{ Specific heat $\left(\mathrm{J} \mathrm{Kg}^{\left.-1{ }^{\circ} \mathrm{C}^{-1}\right)}\right.$} & \multirow[t]{3}{*}{$P$ value } \\
\hline & \multicolumn{5}{|l|}{ Brix } & \\
\hline & 13.6 & 21.0 & 29.0 & 37.0 & 45.0 & \\
\hline 1 & $3728.7 \pm 4^{\mathrm{eA}}$ & $3571.7 \pm 20^{\mathrm{dB}}$ & $3322.2 \pm 5^{\mathrm{dC}}$ & $3144.9 \pm 32^{\mathrm{dD}}$ & $2986.8 \pm 48^{\mathrm{bE}}$ & $<0.001$ \\
\hline 10 & $3746.6 \pm 4^{\mathrm{deA}}$ & $3557.1 \pm 12^{\mathrm{dB}}$ & $3340.2 \pm 5^{\mathrm{cdC}}$ & $3163.0 \pm 30^{\mathrm{cdD}}$ & $3018.9 \pm 57^{\mathrm{abE}}$ & $<0.001$ \\
\hline 19 & $3764.6 \pm 4^{\mathrm{deA}}$ & $3585.0 \pm 17^{\mathrm{cdB}}$ & $3358.1 \pm 10^{\mathrm{cdC}}$ & $3181.2 \pm 30^{\mathrm{bcdD}}$ & $3045.5 \pm 61^{\mathrm{abE}}$ & $<0.001$ \\
\hline 28 & $3782.5 \pm 9^{\mathrm{cdA}}$ & $3603.0 \pm 17^{\mathrm{bcdB}}$ & $3393.8 \pm 23^{\mathrm{bcC}}$ & $3199.3 \pm 32^{\mathrm{bcdD}}$ & $3081.2 \pm 70^{\mathrm{abE}}$ & $<0.001$ \\
\hline 37 & $3820.4 \pm 18^{\mathrm{bcA}}$ & $3644.3 \pm 37^{\mathrm{abcB}}$ & $3430.9 \pm 32^{\mathrm{abc}}$ & $3217.4 \pm 33^{\mathrm{bcdD}}$ & $3099.9 \pm 71^{\mathrm{abE}}$ & $<0.001$ \\
\hline 46 & $3859.8 \pm 24^{\mathrm{abA}}$ & $3662.4 \pm 34^{\mathrm{abB}}$ & $3449.0 \pm 32^{\mathrm{abC}}$ & $3280.7 \pm 57^{\mathrm{abcD}}$ & $3118.6 \pm 71^{\mathrm{abE}}$ & $<0.001$ \\
\hline 56 & $3880.0 \pm 24^{\mathrm{aA}}$ & $3682.6 \pm 34^{\mathrm{abB}}$ & $3469.2 \pm 32^{\mathrm{aC}}$ & $3255.7 \pm 33^{\mathrm{abD}}$ & $3042.3 \pm 31^{\mathrm{abE}}$ & $<0.001$ \\
\hline 66 & $3900.1 \pm 24^{\mathrm{aA}}$ & $3663.0 \pm 5^{\mathrm{aB}}$ & $3486.3 \pm 35^{\mathrm{aC}}$ & $3337.8 \pm 51^{\mathrm{aD}}$ & $3160.2 \pm 33^{\mathrm{aE}}$ & $<0.001$ \\
\hline$P$ value & $<0.001$ & $<0.001$ & $<0.001$ & $<0.001$ & 0.036 & \\
\hline \multirow[t]{3}{*}{ Temperature $\left({ }^{\circ} \mathrm{C}\right)$} & \multicolumn{5}{|c|}{ Thermal conductivity $\left(\mathrm{W}\left(\mathrm{m}^{\circ} \mathrm{C}^{-1}\right)\right)$} & $P$ value \\
\hline & \multicolumn{5}{|l|}{ Brix } & \\
\hline & 13.6 & 21.0 & 29.0 & 37.0 & 45.0 & \\
\hline 1 & $0.491 \pm 0.010^{\mathrm{A}}$ & $0.463 \pm 0.005^{\mathrm{B}}$ & $0.431 \pm 0.000^{\mathrm{C}}$ & $0.400 \pm 0.005^{\mathrm{D}}$ & $0.369 \pm 0.005^{\mathrm{E}}$ & $<0.001$ \\
\hline 10 & $0.493 \pm 0.001^{\mathrm{A}}$ & $0.464 \pm 0.002^{\mathrm{B}}$ & $0.433 \pm 0.001^{\mathrm{C}}$ & $0.402 \pm 0.005^{\mathrm{D}}$ & $0.371 \pm 0.007^{\mathrm{E}}$ & $<0.001$ \\
\hline 19 & $0.494 \pm 0.000^{\mathrm{A}}$ & $0.465 \pm 0.003^{\mathrm{B}}$ & $0.434 \pm 0.002^{\mathrm{C}}$ & $0.403 \pm 0.005^{\mathrm{D}}$ & $0.373 \pm 0.007^{\mathrm{E}}$ & $<0.001$ \\
\hline 28 & $0.496 \pm 0.002^{\mathrm{A}}$ & $0.467 \pm 0.003^{\mathrm{B}}$ & $0.436 \pm 0.004^{\mathrm{C}}$ & $0.405 \pm 0.006^{\mathrm{D}}$ & $0.375 \pm 0.008^{\mathrm{E}}$ & $<0.001$ \\
\hline 37 & $0.497 \pm 0.003^{\mathrm{A}}$ & $0.469 \pm 0.007^{\mathrm{B}}$ & $0.437 \pm 0.005^{\mathrm{C}}$ & $0.406 \pm 0.005^{\mathrm{D}}$ & $0.377 \pm 0.008^{\mathrm{E}}$ & $<0.001$ \\
\hline 46 & $0.499 \pm 0.004^{\mathrm{A}}$ & $0.471 \pm 0.006^{\mathrm{B}}$ & $0.439 \pm 0.005^{\mathrm{C}}$ & $0.409 \pm 0.009^{\mathrm{D}}$ & $0.380 \pm 0.008^{\mathrm{E}}$ & $<0.001$ \\
\hline 56 & $0.501 \pm 0.006^{\mathrm{A}}$ & $0.472 \pm 0.006^{\mathrm{B}}$ & $0.441 \pm 0.005^{\mathrm{C}}$ & $0.410 \pm 0.006^{\mathrm{D}}$ & $0.378 \pm 0.005^{\mathrm{E}}$ & $<0.001$ \\
\hline 66 & $0.503 \pm 0.006^{\mathrm{A}}$ & $0.473 \pm 0.001^{\mathrm{B}}$ & $0.442 \pm 0.006^{\mathrm{C}}$ & $0.413 \pm 0.005^{\mathrm{D}}$ & $0.384 \pm 0.010^{\mathrm{E}}$ & $<0.001$ \\
\hline$P$ value & 0.195 & 0.162 & 0.103 & 0.249 & 0.364 & \\
\hline
\end{tabular}

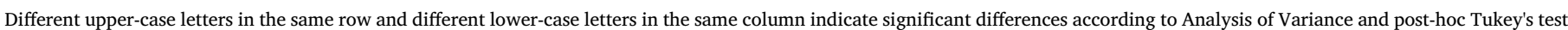
$(\alpha=0.05)$.

resulted in a null $\tau_{0}$, meaning that the Ostwald-de Waele rheological model was the best to describe the rheological behavior of the Cabernet Sauvignon concentrates.

Fig. 2 shows the rheograms of the experimental data collected in the different soluble solid contents of the Cabernet Sauvignon juice concentrates ranging from $1{ }^{\circ} \mathrm{C}$ to $66^{\circ} \mathrm{C}$ using the Ostwald-de Waele rheological model. The relationship between the shear rate and shear stress showed a non-Newtonian behavior of the concentrates assessed with a concave curve downward pattern, assuming a pseudoplastic behavior. The results showed a decrease in the consistency level as the temperature increased and concentration decreased. These behavior present relevant importance in juice processing especially during pasteurization, since high values of consistency level will cause a decrease in the flowing rate in pipe due to the flow resistance. This behavior will result in a stronger heating and longer holding time during pasteurization (Quek et al., 2013).

\subsection{Effect of concentration on rheological behavior of Cabernet Sauvignon concentrates}

The effect of the concentration on the consistency level $(\mathrm{k})$ and flow behavior index (n) for eight different temperatures is listed in Table 2. The results showed the significant reduction of the consistency level (k) as the temperature increase $(P<0.001)$ and this result corroborate the reported by some important studies (Dak, Verma, \& Jaaffrey, 2007; Quek et al., 2013; Vandresen, Quadri, de Souza, \& Hotza, 2009). There is no particular pattern to the flow behavior index results with the variation of the temperature, at the same concentration. These results showed significant differences $(P<0.001)$ when compared to the different temperatures; however, the statistical differences among the flow behavior indexes did not followed a pattern, i.e., in some cases, the flow index was higher at higher temperatures (21 and 45 Brix) and in other cases, the flow index was higher at lower temperatures (13.6, 29 and 37 Brix).

The aforementioned result is in accordance to the reports of Dak et al. (2007) who reported the rheological behavior of "Kesar" mango 

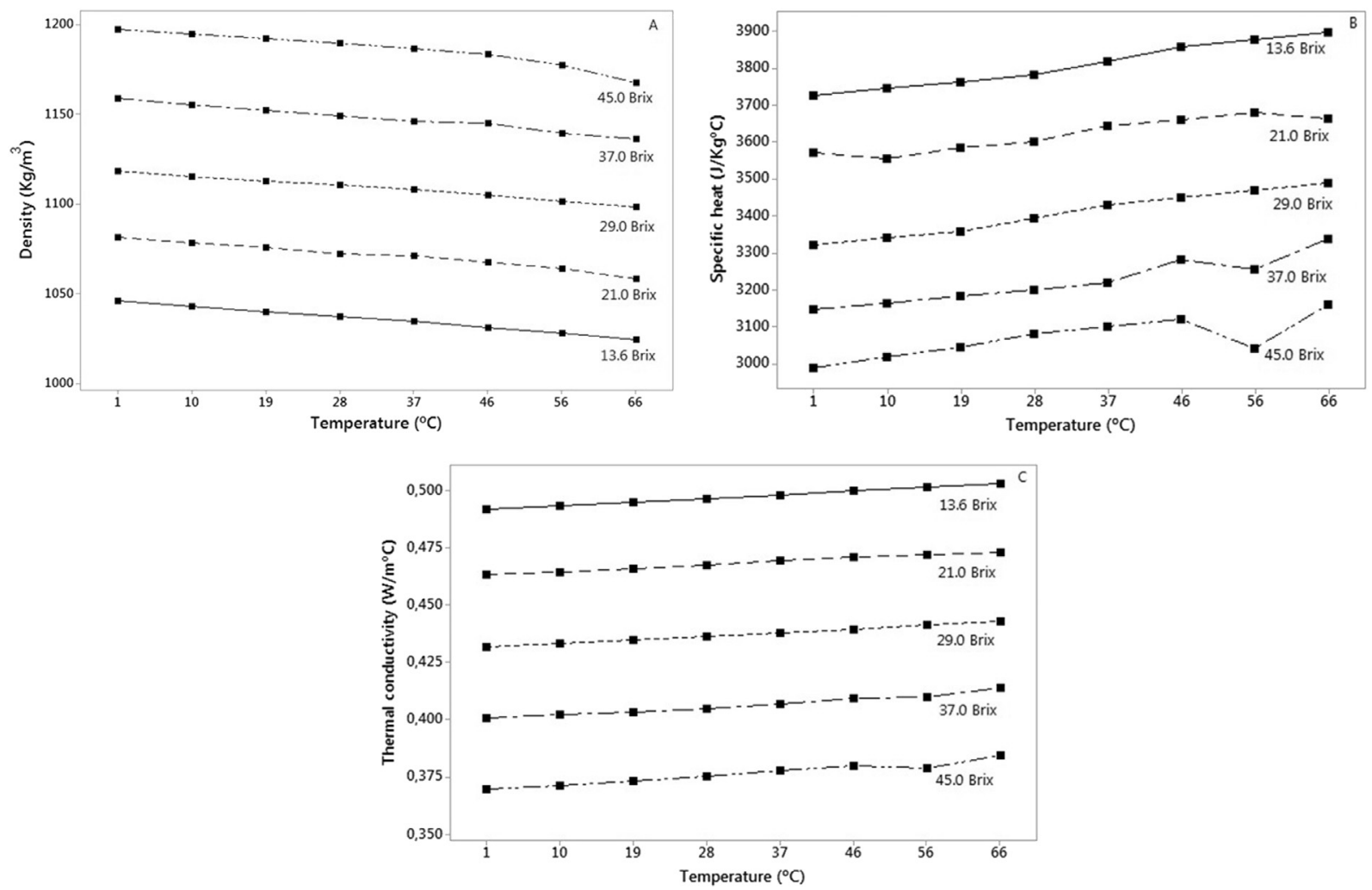

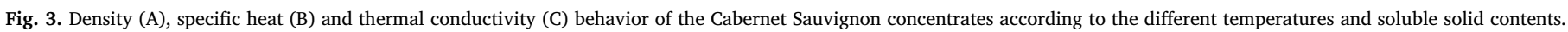

juice and the effect of temperature and different concentrations; and Ahmed, Ramaswamy, and Sashidhar (2007) who reported the rheological characteristics of tamarind juice concentrates; however, disagree with other studies such as Quek et al. (2013) who reported the rheological behavior of soursop juice concentrates and Ibarz, Garvin, and Costa (1996) who reported the rheological behavior of Sloe fruit juices and also reported an increase of the flow index as a result of the increase of the temperature. These results presented relevant changes according to the raw material that has been analyzed, since each source present a punctual flow behavior even presenting the same rheological model behavior.

\subsection{Effect of temperature on rheological parameters}

The effect of the temperature on the consistency coefficient of the Ostwald-De Waele rheological model was described by the Arrhenius relationship. Table 3 shows the parameters, frequency factor and activation energy from Arrhenius relationship at different concentrations with their respective $R^{2}$. The values of activation energy from the concentrates presented significant differences $(P=0.029)$ as a result of the variation of the different concentrations, showing that the activation energy of the juice concentrate at $37.0 \mathrm{Brix}(38.05 \mathrm{KJ} / \mathrm{mol}) \mathrm{sig}$ nificantly differed from the juice concentrate at 45.0 Brix $(28.87 \mathrm{KJ} /$ mol).

As previously stated, the results showed a slight tendency in consider that the higher concentration, the lower the activation energy of the grape juice concentrates. Studies showed that the activation energy presents some inconsistency when analyzed with the variation of the concentration, since the activation energy itself strongly varied due to the different raw materials (Altan \& Maskan, 2005; Belibağli \& Dalgic, 2007; Ibarz, Gonzalez, \& Esplugas, 1994; Kaya \& Belibağli, 2002). Despite this, the results obtained for the activation energy are fitted in a reasonable range for grape juice as reported by Zuritz et al. (2005). Activation energy is a parameter that indicates the sensitivity of the viscosity to temperature variations. According to Kaya and Sözer
(2005), higher activation energy accounts higher sensitivity of the viscosity due to the influence of the temperature.

\subsection{Effect of temperature and concentration on density, specific heat and thermal conductivity}

The effect of the different temperatures and concentrations on the density, specific heat and thermal conductivity is shown in Table 4 (Fig. 3). The results showed that density and specific heat were influenced by the different temperatures and concentrations $(P<0.05)$; however, thermal conductivity presented a relevant influence only by the different concentrations, and the changes in the temperature provided no evidences about significant differences among the thermal conductivity of the Cabernet Sauvignon concentrates $(P>0.05)$.

The increase of the temperature promoted the reduction of the Cabernet Sauvignon juice densities considering the same soluble solid content. As the concentration increase, the density also increase, accounting for an expected result, since the density is directly correlated with the increase of the soluble solid content of the concentrates. Specific heat increased with the higher temperatures; however, this parameter presented lower values for the higher concentration. The correlation between the specific heat and the concentration of the Cabernet Sauvignon concentrates is negative. Temperature was not a significant factor for the increase of the thermal conductivity; however, the aforementioned parameter was strongly influenced by the different concentrations assessed, presenting a significant reduction in the higher concentrations.

The density of the Cabernet Sauvignon concentrates ranged from 1024.6 (at $13.6 \mathrm{Brix}$ and $66^{\circ} \mathrm{C}$ ) to $1197.2 \mathrm{~kg} \mathrm{~m}^{-3}$ (at $45.0 \mathrm{Brix}$ and $1{ }^{\circ} \mathrm{C}$ ) and these results are in accordance with the previous reports of Rizzon and Link (2006) and Zuritz et al. (2005). The specific heat presented values ranging from 2986.8 (at $45.0 \mathrm{Brix}$ and $1{ }^{\circ} \mathrm{C}$ ) to $3900.1 \mathrm{~J} \mathrm{Kg}^{\circ} \mathrm{C}^{-1}$ (at $13.6 \mathrm{Brix}$ and $66^{\circ} \mathrm{C}$ ) and these aforementioned results are in accordance with previous reports of Moura, França, and Leal (2003). The thermal conductivity results ranged from 0.369 (at 
45.0 Brix and $1{ }^{\circ} \mathrm{C}$ ) to $0.503 \mathrm{~W} \mathrm{~m}^{\circ} \mathrm{C}^{-1}$ (at $13.6 \mathrm{Brix}$ and $66^{\circ} \mathrm{C}$ ) which presented a relative proximity of the results obtained by Oliveira, Camargo, Machado, and Borges (2001). All the obtained results were in accordance with previous results by Ikegwu and Ekwu (2009) who reported the physical properties of several juices elaborated from tropical fruits. In addition, Magerramov (2007) reported that the temperature was a significant factor that influenced the heat capacity of apple, cherry and raspberry juices, contrasting the results obtained in this present study which accounted for an insignificant influence of the temperature in thermal conductivity.

The obtained results were important and useful in the calculation of heat, mass and momentum transfer, avoiding loss of calculation precision. The range of the temperature assessed in this study associated with the rheological behavior is also important since the fluids and juices are considered extremely different according to the raw material and source. In addition, the thermal treatment also had a strong influence on physical properties such as density and specific heat, modifying these intrinsic properties of the juice which can be responsible to change some chemical components.

There have been a lack of studies showing results of these parameters for grape juice, not only for Cabernet Sauvignon juices, but for all grape cultivars and the assessment of these aforementioned parameters for Cabernet Sauvignon concentrates is very useful in order to enhance the quality of the juice processing, allowing the enrichment and the optimization of the processes involving juice production with excellent quality.

\section{Conclusions}

The rheological behavior of the Cabernet Sauvignon juice concentrates was satisfactorily described by the Ostwald-De Waele model. The obtained results showed that the consistency level $(\mathrm{k})$ reduces as the temperature increases and the flow index behavior presented higher and lower values in higher temperatures depending on the concentration of the grape juice. There is a controversy among the several studies about the values of activation energy of the juices from different sources and raw materials; however, it is feasible to notice that the activation energy of the fluid is directly correlated with its temperature sensitivity. Density and specific heat were significantly influenced by temperature as well as by the different concentrations. The thermal conductivity was only significantly influenced by the different soluble solid contents assessed, i.e., the temperature was not strongly related with the thermal conductivity since it was possible observing slightly changes when temperature varied.

A future research will comprise the assessment of the Cabernet Sauvignon concentrates as wine chaptalization agent in order to replace the sucrose. This will elucidate the chemical and sensory changes using the juice concentrate instead of the direct application of the sucrose in wine chaptalization. In addition, Merlot juice concentrates physical properties and rheological behavior will be published as a second part of this project improving the study of the grape concentrates as chaptalization agent and enhancing the data about the rheological behavior which is relevant for producers and wineries.

\section{References}

Ahmed, J., Ramaswamy, H. S., \& Sashidhar, K. C. (2007). Rheological characteristics of tamarind (Tamarindus indica L.) juice concentrates. LWT-Food Science and Technology, 40, 225-231.

Altan, A., \& Maskan, M. (2005). Rheological behavior of pomegranate (Punica granatum
L.) juice and concentrate. Journal of Texture Studies, 36, 68-77.

Arched, D. G. (1993). Thermodynamic properties of synthetic sapphire (a-A1203) standard reference material 720 and the effect of temperature-scale differences on thermodynamic properties. Journal of Physical and Chemical Reference Data, 22 1441-1453.

ASTM E1269-11 (2005). Standard test method for determining specific heat capacity by differential scanning calorimetry. West Conshohocken: ASTM International.

Augusto, P. E. D., Ibarz, A., \& Cristianini, M. (2012). Effect of high pressure homogenization (HPH) on the rheological properties of a fruit juice serum model. Journal of Food Engineering, 111, 474-477.

Belibă̆li, K. B., \& Dalgic, A. C. (2007). Rheological properties of sour-cherry juice and concentrate. International Journal of Food Science and Technology, 42, 773-776.

Brasil (2005). Altera dispositivos da Lei n. 7678 de 8 de novembro de 1988Brasília: Diário Oficial da União.

Carvalho, G. R., Chenlo, F., Moreira, R., \& Telis-Romero, J. (2015). Physicothermal properties of aqueous sodium chloride solutions. Journal of Food Process Engineering, $38,234-242$.

Dak, M., Verma, R. C., \& Jaaffrey, S. N. A. (2007). Effect of temperature and concentration on rheological properties of "Kesar" mango juice. Journal of Food Engineering, 80, 1011-1015.

Galant, A. L., Widmer, W. W., Luzio, G. A., \& Cameron, R. G. (2014). Characterization of molecular structural changes in pectin during juice cloud destabilization in frozen concentrated orange juice. Food Hydrocolloids, 41, 10-18.

Gratão, A. C. A., Silveira, V., Jr., \& Telis-Romero, J. (2007). Laminar flow of soursop juice through concentric annuli: Friction factors and rheology. Journal of Food Engineering, $78,1343-1354$.

Ibarz, A., Garvin, A., \& Costa, J. (1996). Rheological behaviour of sloe (Prunus spinosa) fruit juices. Journal of Food Engineering, 27, 423-430.

Ibarz, A., Gonzalez, C., \& Esplugas, S. (1994). Rheology of clarified fruit juices. III: Orange juices. Journal of Food Engineering, 21, 485-494.

Ikegwu, O. J., \& Ekwu, F. C. (2009). Thermal and physical properties of some tropical fruits and their juices in Nigeria. Journal of Food Technology, 7, 38-42.

Kaya, A., \& Belibağli, K. B. (2002). Rheology of solid Gazıantep Pekmez. Journal of Food Engineering, 54, 221-226.

Kaya, A., \& Sözer, N. (2005). Rheological behaviour of sour pomegranate juice concentrates (Punica granatum L.). International Journal of Food Science and Technology, 40, 223-227.

Magerramov, M. A. (2007). Heat capacity of natural fruit juices and of their concentrates at temperatures from 10 to $120^{\circ} \mathrm{C}$. Journal of Engineering Physics and Thermophysics, 80, 1055-1063.

Moura, S. C. S. L., França, V. C. L., \& Leal, A. M. C. B. (2003). Thermophysical properties of model solutions similar to juice - Part I. Food Science and Technology, 23, 62-68.

Neto, F. S. P. P., De Castilhos, M. B. M., Telis, V. R. N., \& Telis-Romero, J. (2014). Effect of ethanol, dry extract and reducing sugars on density and viscosity of Brazilian red wines. Journal of the Science of Food and Agriculture, 95, 1421-1427.

Oliveira, S. D., Camargo, D., Machado, P. P., \& Borges, S. V. (2001). Thermal conductivity of orange juice. Revista Brasileira de Produtos Agroindustriais, 3, 101-104.

Perry, R. H., \& Chilton, C. H. (1986). Manual de Engenharia Química. Rio de Janeiro: Guanabara Dois.

Quek, M. C., Chin, N. L., \& Yusof, Y. A. (2013). Modelling of rheological behavior of soursoup juice concentrates using shear rate-temperature-concentration superposition. Journal of Food Engineering, 118, 380-386.

Radovanovic, A., Jovancicevic, B., Arsic, B., Radovanovic, B., \& Bukarica, L. G. (2016) Application of non-supervised pattern recognition techniques to classify Cabernet Sauvignon wines from the Balkan region based on individual phenolic compounds. Journal of Food Composition and Analysis, 49, 42-48.

Rizzon, L. A., \& Link, M. (2006). Composition of homemade grape juice from different varieties. Ciência Rural, 36, 689-692.

Rizzon, L. A., \& Miele, A. (2002). Evaluation of the cv. Cabernet Sauvignon in the manufacture of red wine. Food Science and Technology, 22, 192-198.

Rojas, M. L., Leite, T. S., Cristianini, M., Alvim, I. D., \& Augusto, P. E. D. (2016). Peach juice processed by the ultrasound technology: Changes in its microstructure improve its physical properties and stability. Food Research International, 82, 22-33.

StatSoft Inc. (2014). Tulsa, OK: Statistica 12.

Telis-Romero, J., Gabas, A. L., Polizelli, M. A., \& Telis, V. R. N. (2000). Temperature and water contente influence on thermophysical properties of coffee extract. International Journal of Food Properties, 3, 375-384.

Telis-Romero, J., Thomaz, C. E. P., Bernardi, M., Telis, V. R. N., \& Gabas, A. L. (2006). Rheological properties and fluid dynamics of egg yolk. Journal of Food Engineering, 74, 191-197.

Vandresen, S., Quadri, M. G. N., de Souza, J. A. R., \& Hotza, D. (2009). Temperature effect on the rheological behavior of carrot juices. Journal of Food Engineering, 92, 269-274.

Zuritz, C. A., Muñoz Puntes, E., Mathey, H. H., Pérez, E. H., Gascón, A., Rubio, L. A., .. Cabeza, M. S. (2005). Density, viscosity and coefficient of thermal expansion of clear grape juice at different soluble solid concentrations and temperatures. Journal of Food Engineering, 71, 143-149. 